\title{
Impact of Selected Indicators of Tourism Capacity and Performance in the Context of the Unemployment Rate in Slovakia
}

\author{
Mária Matijová \\ Faculty of Management, University of Prešov, Slovakia \\ Erika Onuferová \\ Faculty of Management, University of Prešov, Slovakia \\ Martin Rigelský \\ Faculty of Management, University of Prešov, Slovakia \\ Vladislav Stanko \\ Faculty of Management, University of Prešov, Slovakia
}

Received: 10 May 2019. Revision received: 21 July 2019. Accepted: 30 July 2019

\begin{abstract}
Tourism is considered to be the largest service sector leading to a number of social and economic changes. The aim of this paper is to deduce the impacts of selected indicators of capacity and performance of tourism (such as number of accommodation facilities, number of beds, number of visitors in accommodation facilities, number of visitor's overnight stays, average price of accommodation, and revenue of accommodation) on the socio-economic development of the national economy quantified by the rate of registered unemployment. The data were obtained from database of Statistical Office of the Slovak Republic on annually period. The analysis was carried out at the NUTS 3 level of Slovakia in the period between 2008 and 2017. Determining the extent of the impact of tourism capacity and profit potential indicators on the rate of registered unemployment in Slovakia has shown the supreme importance embodied in the average price for accommodation, confirmed by the result of the regression analysis, concluding that the unemployment rate decreases as the average price for accommodation increases. The analyses described were carried out using regression models, where the resulting relation between the price of accommodation and unemployment was conducted by using the simple linear regression. The reasearch added value consists in the finding that one of the factors of the decrease in the unemployment rate is the support of the production potential of tourism, conditioned by the quality of the services offered, which are reflected in higher prices for accommodation. In the context of research conclusions, contributions are considerable for private and public sectors. For practice, we recommend to pay more attention to analyse of price for goods or services provided, as well as, to create suitable enterprise environment by creating efective tourism strategy in order to increase employment.
\end{abstract}

Key words: Tourism, Indicators of tourism performance and capacity, Rate of registered unemployment, Multiplication effect of tourism, Slovakia.

JEL Classification: O12, O50, Z32.

\section{Introduction}

Tourism ranks among the most important and fastest growing sectors of national economies, as it is already making a significant contribution to building long-term 
competitiveness through its performance. As stated by Kajzar (2018), the dynamics of development have turned tourism into a key driver for socioeconomic progress. At the global level, tourism represents a crucial economic component. At present, the tertiary sector represents a significant part of developed economies (60\% of GDP) and it is the fastest growing sector in Slovakia (Kisel'áková, Šofranková, Čabinová, Šoltésová, 2018). Therefore, countries have incorporated tourism into their long-term economic development planning systems. Although the link between the economic growth and tourism development is obvious, Karaoulanis (2018) emphasizes that tourism development is a product of economic growth and not the other way round.

Justification of the importance of the tourism sector in the international context is also highlighted by the World Economic Forum (WEF). On the global scale, the development of tourism is analyzed by the WEF through the so-called. Travel \& Tourism Competitiveness Index (TTCI), which regularly evaluates over 130 countries worldwide. The index is a comprehensive strategic tool for measuring a set of different factors that determine the sustainable development of tourism. Based on the results of the analyses performed by the WEF (2017) it is clear that the tourism industry continues to make a real difference to the lives of millions of people by driving growth-creating jobs, reducing poverty and fostering development and tolerance. Tourism contributed US \$ 7.6 trillion to the global economy (10.2\% of the global GDP) and generated 292 million jobs ( 1 in 10 jobs on the planet). These promising figures are expected to continue increasing in the coming decade. In terms of regional results compiled by the UNWTO (2018), Europe has been the world's most visited region for the eighth year in succession. The total number of arrivals in Europe in 2017 increased by $8 \%$ ( 52 million people) compared to the previous year with a total of 672 million tourists. The increasing number of visitors was subsequently reflected in the total tourism revenues, which in 2017 also increased by $8 \%$ to $\$ 519$ billion.

The development of tourism is closely linked with new trends, which are determined mainly by social, economic, social-welfare, political and demographic changes. As reported by Štefko, Gavurová, Korony (2016), there are different conditions as well as economic, health and social bonds in the countries, while a constant emphasis on efficiency is the common feature in each country. The European Commission has defined 10 basic trends in tourism that will significantly influence its future development (Kotíková, 2013). These include demographic changes, an emphasis on health and wellness, education and access to information, prolonging the leisure time, improving travel experience, lifestyle, and information technology.

In Slovakia, due to its natural and cultural potential, tourism takes an important position in the national economy. Moreover, due to the historical context, the religious tourism also started to play a significant role in tourism development in Slovakia (Štefko, Királ'ová, Mudrík, 2015). The positive trend in the tourism industry is associated with all the kinds of economic effects. Nevertheless, tourism does not receive sufficient economic or political recognition. Slovakia, like many other countries, faces the challenge of strengthening and improving tourism development in order to ensure the long-term competitiveness of this sector. The endeavour is to support the development of tourism in the capacity of our resources, in which the optimization of immediate economic, environmental, and sociocultural benefits will be balanced with ensuring the sustainable development of the country. The strategic objective of State-pursued tourism policy is to increase its competitiveness while better exploiting its potential, with a view to balancing regional disparities so as to ensure and improve the quality of life and to make the national economy as beneficial as possible. For the purpose of monitoring the overall economic contribution of tourism in Slovakia, a Satellite Tourism Account was created, which was compiled by the Statistical Office of the Slovak Republic (SOSR). The Ministry of Transport, Construction, and 
Regional Development (MTCRD) and the National Bank of Slovakia (NBS) also participate in that cooperation. An overview of the structure of State authorities operating in Slovakia in the tourism sector is presented in the Table 1 .

Table 1

Structure of tourism authorities in Slovakia

\begin{tabular}{llc}
\hline Level & Entity / Organisation & Number \\
\hline \hline \multirow{2}{*}{ National } & Ministry of Transport, Construction, and Regional Development of & 1 \\
& the Slovak Republic (MTCRD) & 1 \\
\multirow{2}{*}{ Regional } & Higher territorial unit (HTU) & 8 \\
& Regional Tourism Organizations (RTO) & 7 \\
\hline \multirow{2}{*}{ Local } & Areal tourism organizations (ATO) & 37 \\
& Tourist information centres & 54 \\
& Municipalities & 2,927 \\
\hline
\end{tabular}

Source: MTCRD 2018

In this regard, Simionescu (2016) emphasised the importance of regional tourism development and sustainable competitiveness. Changes in the consumption of tourism in the Czech Republic in the years 2007 to 2011 based on the data for the Tourism Satellite Account using available indicators was analyzed also by Mertlova, Smith (2014). The research was implemented in the sphere of tourism in relation to unemployment in the sector. As reported by Hamarneh, Királová (2016), tourism is a significant part of the economy and is playing a significant role in the regional developmentas well. According to Badelescu (2015), tourism has a considerable capacity to promote regional development, stimulate the development of the related sectors, and has a major impact on the country's living and economic development (Ohanyan, Androniceanu, 2017). For example, Schmude, Zavareh, Schwaiger, Karl (2018); Sultana (2016); Pratt (2015); Plzáková, Studnička (2014); Štefko, Vašanicová, Litavcová, Jenčová (2018) are examining various aspects determining tourism development from the perspective of regional development. In the context of information provided in introduction, the aim of the aim of this paper was to deduce the impacts of the selected indicators of tourism at regional level of Slovakia on the socio-economic development of the economy quantified by the indicator of the registered unemployment rate.

\section{Literature review}

Over the past decades, tourism has been steadily increasing, as well as the importance of the tourism industry for the economy of many countries in the world. Tourism is a mass phenomenon influencing all the components of the macro environment and to contribute significantly to the sustainable economic development of society. For this reason, in the presented paper we have analyzed the impact of tourism on the economic development from the perspective of the unemployment rate indicator as a basic macro-economic metric.

The issue of sustainable development is a fast developing area of surveys (Kot, 2018; Semenenko et al., 2019). Currently, there are many research lines regarding the capacity of tourism and its influence on the level of economic development. Because of the assumption that tourism will lead to economic growth and development, many research papers have examined the relationship between tourism development (measured by different statistics) and the economic growth. In this regard, Latifian, Madahi, Mabhout (2018) determined whether economic growth in certain countries has led to an increase in the economic development due 
to the expansion of tourism activity. The results indicated that this relationship exists, and tourism is a driving force of economic development. Ghosh (2019) explored the causal association of economic uncertainty between tourism and other macroeconomic variables over the period 1995 to 2016 in the selected countries. In the long run, uncertainty adversely affects the tourism industry.

In literature, there are many studies on the effects of tourism promotion on (un)employment. According to Bakri, Jaafar, Mohamad (2014), the tourism sector has an ability to generate and increase income, employment, and raise the living standards. Therefore, the investment in tourism development should be of interest to the governments as it helps ensuring the economic benefits. In short, the consumption of goods and services by tourists visiting a destination has an impact on the production, income, employment, tax revenue, prices, and so on (UNWTO, 2015). Traditionally, the role of tourism has been recognized as an instrument of endogenous development and, therefore, it has its potential to generate wealth and employment, provided the right circumstances are in place. The tourism industry is internationally a rapid growing industry, it contributes to the economic enhancement, as well as it generates employment opportunities (Pulido-Fernandez, PulidoFernandez, 2018). The contribution of tourism (e. g., expressed in overnight stay by tourists) to the GDP and employment was addressed by Petcu, Cismasu (2019). The empirical study highlights that there is a significant correlation between macroeconomic and tourism indicators, and the assertion that tourism generates direct effects on the employment rate was verified. In this context, Schubert (2013) investigated the effects of an increase in tourism demand on unemployment. The demand of tourists may either rise exogenously (for example, owing to an increase in foreigners' income) or because of advertising efforts of the domestic country. The model developed in the paper has supported the popular view that tourism can reduce unemployment. Yabuuchi (2018) examined the effects of tourism on the production and employment. The main finding of the study was that under certain conditions, tourism promotion expands the tourism sector, reduces unemployment, and improves welfare. The research study of Yrigoy (2014) was based on the premise that there is no automatic relationship between the above-mentioned dimensions. However, the paper results have confirmed that the existence of low unemployment rates have contributed to the transformation of tourism growth into the economic development. The paper by Eusebio, Carneiro, Kastenholz, Alvelos (2016) assessed the economic relevance of tourism programmes based on two simultaneous approaches: an analysis of the stakeholders' perceptions of the economic impacts and a quantitative assessment of the impacts on the national economy. An integrated model was used to estimate the total economic impact of tourism on the output, household income, employment, and added value. The quantitative assessment revealed high total economic impacts regarding profitability, employment, and attracting new visitors. As stated by Kadriu (2016), tourism has in fact a large impact on the economic growth of a country. Apart from the obvious benefits, there are many indirect impacts that are not noticeable but evident in the economy. The author aimed to outline the economic impact of tourism to growth and development of a country, especially by creating new jobs. By examining various economic factors, we may begin to understand the benefits of tourism in the GDP and the overall stability of the economy through higher employment. Job creation can be much higher in the tourism industry as opposed to any other industry because of the indirect effects and trickle down the effect of tourism activities. The majority of jobs generated in the tourism industry is accounted for in hotels and accommodation facilities. These numbers can reach a high percentage of the tourism employment. In every hotel room, there are multiple tasks that must be conducted on a daily basis allowing for the creation of many jobs. The performance of tourism itself is measured by various indicators and methods. As reported by Modica, Capocchi, Foroni, Zenga (2018), in the context of tourism 
performance measurement system, the European Union (EU) has created the European Tourism Indicators System (ETIS) within the Sustainable Development Strategy, which was formulated with the objectives of promoting the economic prosperity, social equity, cohesion, and environmental protection. The ETIS includes four categories of indicators, such as destination management, social and cultural impact, economic value, and environmental impact. The authors implemented the above-mentioned system in their research paper and the findings revealed that an adaptive management approach is necessary for achieving the anticipated objectives and adapting these standardized indicators to different territorial contexts. Vengesayi, Mavondo, Reisinger (2016) addressed the influence of tourist attractions, facilities, support services, and people as the main predictors of tourism on the tourism attractiveness. The authors consider all these factors the main determinants of tourism attractiveness. The tourism overview through its indicators was analysed by Camilleri (2018). The author explained the tourists' inherent motivations to travel, as well as other different aspects that together make up the tourism industry. If a tourist decides to travel, the most important decision includes the issues of transportation, price ability, and accommodation. The accommodation sector comprises different forms of facilities, while hotels are the most significant and widely recognised service providers of overnight accommodation for tourists. From this perspective as the author concluded, all of the above-mentioned variables exert an impact on the tourism development. Wanke, Figueiredo, Antunes (2019) presented a comprehensive analysis on the relation that may exist between macroeconomic variables and tourism activity expressed by tourism revenue/expenditures. While tourism revenues are autocorrelated and impacted economic growth, tourism expenditures are detached from any macroeconomic variable. It is known that tourism has become an important dimension in the economy of international trade in the recent years. The relationship between tourism revenue, economic growth, and its implications for the environment was evaluated by Banday, Ismail (2017). The panel data analysis was applied for the period of 1995-2013. The result validates 'tourism led-growth hypothesis' that the growth of tourism, expressed by tourism revenues, has a positive impact on the economic growth. For analyzing tourism performance, Purwomarwanto, Ramachandran (2015) used many other indicators. According to the authors, tourism contributes to the growth of economy of a nation through employment, multiplier effect, and foreign exchange earnings and also contributes to the positive balance of payments. The authors examined the performance of the tourism sector with regard to the recent global crisis. There were two models used in the study. The first model employs the GDP to represent the economic growth and the number of international tourist arrivals to represent the tourism growth. The second model employed the hotel occupancy rate, the average length of the stay, and the number of tourist arrival as a metrics of the tourism growth. Based on the result obtained, the authors consider tourism development as one of strategic economic pillars. According to Gallo, Mihalčová, Gallo, Jr., Čabinová, Tomčíková (2018); Cepel, Stasiukynas, Kotaskova, Dvorsky (2018), improving the overall results in the tourism sector also depends on the appropriate choice of methods supporting the performance improvement of tourism enterprises, having important effects on the growth of the entire society. In this context, Štefko, Fedorko, Bačík, Fedorko (2015) stated that through good reputation management organization can ensure that it will be positively perceived by the target customers.

Tourism plays an important role in the economic development strategy. In addition, tourism is a very dynamic phenomenon and competition is increasing in the international tourism market. In selecting the variables that entered the tourism analysis, we departed from the following starting points. The most important component in the tourism system should be the participant him/herself as the main traveler and the motivation of their journey. The participant shall mean a person who has remained in a place outside his/her permanent 
residence for at least 24 hours, with the visited territory being an essential feature of the tracking (Gregorová, Neradný, Klaučo, Masný, Balková, 2015). Individuals become tourists when they voluntarily leave their standard surroundings, where they reside, to visit another environment. Therefore, tourists are visitors, and what they do whilst visiting another place may be considered as tourism. Economically speaking, the tourist is a goods consumer and a services beneficiary (Camilleri, 2018; Stefko et al., 2017). Studies by Strielkowski (2018) have reported that for a country to have a successful tourism industry, it needs to meet or even surpass the expectations of visitors. The interest of the client (participant) of tourism depends mainly on the potential of the country, the overall attractiveness, and the availability of the required services. As Malec, Királ'ová (2018) added, the knowledge of the employers' demands on the competencies is very important in the scope of human capital accumulation in the tourism sector. Assessing and monitoring the benefits of tourism plays a key role in the process of assessing the resulting economic effects that this sector brings. Tourism creates added value within the economic, social, and environmental environments (Roy, Roy, 2015). This system represents a complex network of internal and external relations that are needed to be balanced (Dobrovič, Urbanski, Gallo, Benkova, Čabinová, 2018). As reported by Bunghez (2016), a major benefit of tourism in stimulating the economic growth is represented by the increase in the number of available jobs. In addition, policymakers have a special interest in tourism promotion because it can decrease the unemployment rate. Moreover, the tourism sector can bring important revenues to the State budget in the form of taxes and fees paid. Ali (2018) joins this view adding that an important role is played by the total cash receipts (revenues) and tourism spending as important components of the economic value creation. In addition to the positive effects, tourism also has negative impacts. Šofranková, Kiseláková, Horváthová (2017) recommended to identify the weakness of the local sector and to finalize the specific risk of the sector after a careful analysis. In the area of economic influences, Holešinská (2012) ranks here e.g. the loss of the induced income from tourism outside the region's economy or seasonality of travel. Page (2015) recognizes the problem in the seasonal nature of tourism visitors perceiving it as a long-standing concern. Service providers must look for ways to reduce the effects of seasonal nature (market diversification, price adjustment or event management).

The presented research paper measures the contribution of tourism to an economy's growth. We use the unemployment rate indicator for individual regions of Slovakia (SOSR, 2019) as a measure of the economic growth. The reason for the choice was that unemployment is a major factor affecting tourism spending and consumption. As stated by Tüzemen (2017), unemployment can be seen as an economic category that also has a macroeconomic dimension.

\section{Research methodology}

The aim of this paper was to deduce the impacts of the selected indicators of capacity and performance of tourism on the socio-economic development of the national economy quantified by the indicator of the registered unemployment rate. The analysis was carried out for the years 2008 - 2017 at the NUTS 3 level of the Slovakia. For the correct determination of the issue was to evaluate the development of the selected indicators affecting the trend of the development of tourism in Slovakia in the period analysed at the NUTS 1 level.

The analyses included the data obtained from individual regions of Slovakia in the monitored period in the NUTS 3 category (at level of the following regions: Bratislavský, Trnavský, Trenčiansky, Nitriansky, Žilinský, Banskobystrický, Prešovský and Košický). For impact assessment of selected tourism indicators on the unemployment ratio we decided to 
adopted the data at NUTS 3 level, as we use regression analysis. The exact selection of variables (indicators) was determined by the availability of statistical data, which represent the capacities and performances of tourism. Relevant data were obtained from the database of the Statistical Office of the Slovak Republic (SOSR - Tourism Satellite Account, 2019) in cooperation with the MTCRD of the Slovakia.

In the following section, we will focus on a brief description of the selected variables that were part of the analyses performed (Mishchuk et al., 2019). The selection of variables was depended on the availability of statistical data provided by SOSR and the databases of the MTCRD. As stated by these institutes, above-mentioned indicators are relevant for tourism measurement. All applied data are yearly. At the same time, we present descriptive statistics of the selected indicators reflecting the development of tourism (Table 2).

- Tourism accommodation facility - is a tourism establishment that provides temporary or regular accommodation for visitors for the purpose of tourism.

- Beds in tourist accommodation facilities include all the beds for the night's rest, including occasional beds. Not included herein are the beds intended for the owner and the staff of the accommodation facility

- Visitor to a tourist accommodation facility - a person - a traveler who uses the services of a temporary accommodation facility regardless of the country of residence, including children. S/he travels to the main destination outside of his/her usual environment for less than one year, with the main purpose being different from being employed in the visited place or country.

- Number of overnight stays in accommodation faciclities - this is the length of a holiday or business trip with an overnight stay and should not last more than 12 consecutive months; included within that the number are overnight stays that tourists spend outside their usual environment in rented or unlisted public or private accommodation facilities.

- Revenues for visitors' accommodation - these include revenue including the value added tax for overnight visitors, revenue for placing a tent, motor vehicle, trailer, power line, and so on. They also include revenue from accommodation services.

- Unemployment rate - the unemployed to the economically active population is expressed as a percentage.

For intention of analysis which is conditioned by the objective of article we use method determined impact - regression analysis. Regression analysis, e.g. type OLS (4) determines how independent variables affect dependent variable. The use of regression analysis requires several conditions to be met, according to Gauss-Mark's theorem, there is no significant collinearity and Non-constant variation of the residuals (heteroscedasticity). if these conditions are not met, we will be methods of regulations - Ridge, Lasso and Elastic net regression (1-3). On the one hand, these methods of regression analysis measure the effects of independent variables on dependent variables and, on the other hand, those method "filter" independent variables. The output strength of these methods is determined by outputs such as root mean square error (RMSE), coefficient of determination (R2) and prediction (5) that compare data for Train model $(70 \%)$ and Test model $(30 \%)$. The exact effects will be determined by the OLS model (4).

Ridge regression

\section{Lasso regression}

Elastic net regression

$$
S S E_{\text {ridge }}=\sum(y-\hat{y})+\lambda \sum \beta^{2}
$$$$
S S E_{\text {lasso }}=\sum(y-\hat{y})+\lambda \sum|\beta|
$$ 
Linear model of regression analysis $y_{i}=\beta_{0}+\beta_{1} X_{i}+\ldots+\beta_{n} X_{p}+\varepsilon_{i}$.

$$
\text { prediction }=\sqrt{\frac{\sum_{N=1}^{N}\left(Z P_{i}-Z \hat{P}\right)^{2}}{N}}
$$

where $\overline{\boldsymbol{Z}} \overline{\boldsymbol{P}}$ acquires values by a certain type of the regression model.

These methods were used primarily because of the higher correlation of independent variables, but also because of the higher number of given variables. The model enters $\lambda$, which will be estimated in the first parts of the analysis. The analysis will then be continued by determining the importance of the elements. To increase credibility, the data was divided into two parts (train set and test set) at $70 \%$ and $30 \%$.

For analytical data processing was used programing language R (v. 3.4.4), software R studio and libraries caret, glmnet, car, lmtest and psych.

\section{Results}

\subsection{Capacity and profit potential assessment}

In accordance with the partial objective stated, we have focused on a brief evaluation of the development of the variables (indicators) selected reflecting the trend of the development of tourism in Slovakia. The outputs were analyzed for the years 2008 - 2017 using the data obtained from individual regions (analyzing at level NUTS 1 category). We tried to provide a comprehensive current view on tourism sector. The objective of this analysis was to demonstrate its growing importance in the context of the macroeconomic environment development in Slovakia.

When evaluating tourism in Slovakia, we paid attention first to the analysis of indicators representing capacity potential (number of accommodation facilities, number of beds, number of visitors and number of visitor's overnight stays) based on their deveopment over the reporting period (Figure 1). In the context of the capacity potential, the study of Fiala (2017) proves that the firm size is not the key factor which influences the firm growth.

Figure 1

Development of Capacity Potential Indicators of Slovakia in the years 2008 - 2017

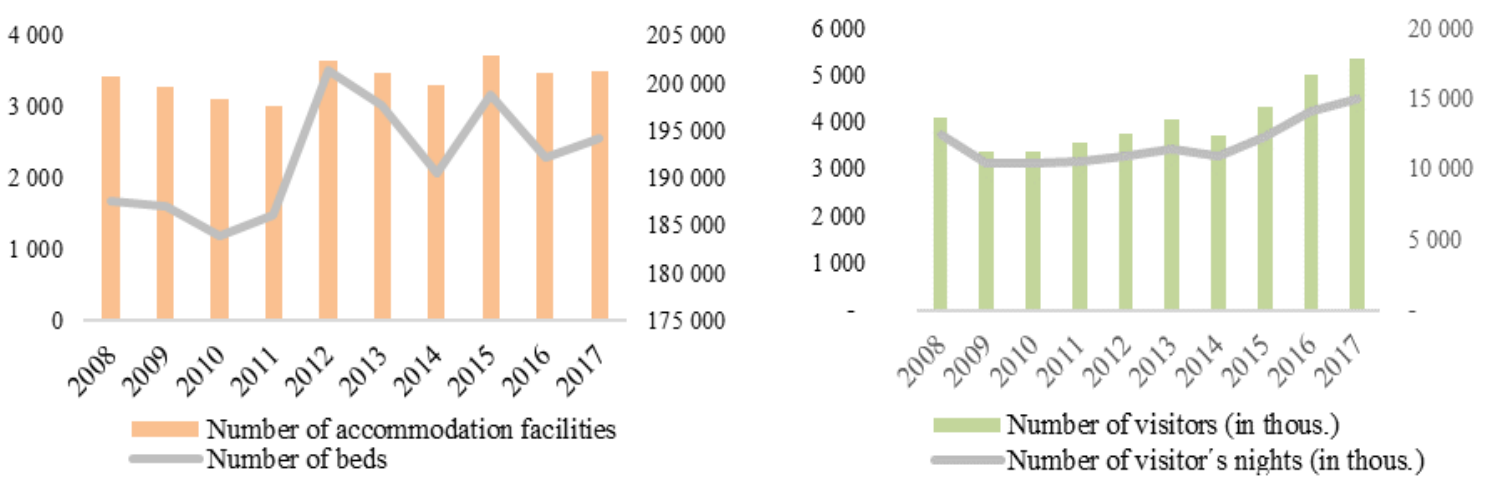

Source: Our own processing

The development of the indicator of the number of accommodation facilities was fluctuating in the period under review, with the range being 713 enterprises. By comparing 
the years 2008 and 2017, we revealed that the number of accommodation facilities in Slovakia did not change significantly within the given period, as it only increased by $1.78 \%$. The highest number of accommodation facilities was registered in the year $2015(3,724)$, while the lowest number of accommodation facilities in this country was in 2011 (3,011). In Slovakia, 3 402 accommodation facilities performed business activities on average over the analyzed period. In the case of the total number of beds indicator, we found significant year-on-year changes, which mostly followed the development of the number of accommodation facilities. The decline in the number of accommodation facilities was accompanied by a decline in beds in tourism establishments, with the exception of the year 2011, when the number of beds increased by $1.23 \%$ despite the decline in accommodation facilities. Accommodation facilities offered the most beds in 2012, while the lowest accommodation capacities were found in 2010. During the period analysed, 17,500 new beds were created and on average, with the number of beds having been 191,989. Within the framework of the tourism analysis from the perspective of the total number of visitors' indicator, we have predominantly quantified the growing trend of development, with the exception of the decrease in 2009 and 2014. Looking at the chart above, it is clear that between 2009 and 2012, the number of visitors did not exceed 4 million. But this is not the case for 2016 and 2017, when the number of visitors was even above 5 million. At the same time, the highest number of visitors was quantified in the last monitored year, while the least guests visited accommodation facilities in 2010. The analysis for 2008 - 2017 also revealed that on average 4,070,708 visitors used the services of accommodation facilities. As expected, the number of overnight stays indicator followed the overall number of visitors. In the period under review, there was an increase in the number of visitors by $2,472,662$, with the highest year-on-year change index of 1.1448 was revealed in 2015. The indicator also showed that between 2008 and 2015, the number of overnight stays did not exceed 12.47 million while in 2016 and 2017, it was on average 14.54 million overnight stays. Based on the analysis, it can also be stated that most of the visitors stayed in accommodation facilities in 2017 and the least number of them stayed there in the year 2010 . The number of overnight stays in accommodation facilities in Slovakia was 11,846,771.

We supplement the analysis of tourism in Slovakia by evaluating the profit potential for the period under review (Figure 2). As regards the link between economic efficiency and profitability in the tourism sector, no significant relationship between profitability and business efficiency has been identified (Hedija, Fiala, Kuncová, 2017). In the context of selected indicators that entered into further analyses, we quantified the profit potential using the average price of accommodation and revenue of accommodation.

Figure 2

Development of indicators of profit potential of Slovakia in the years 2008 - 2017

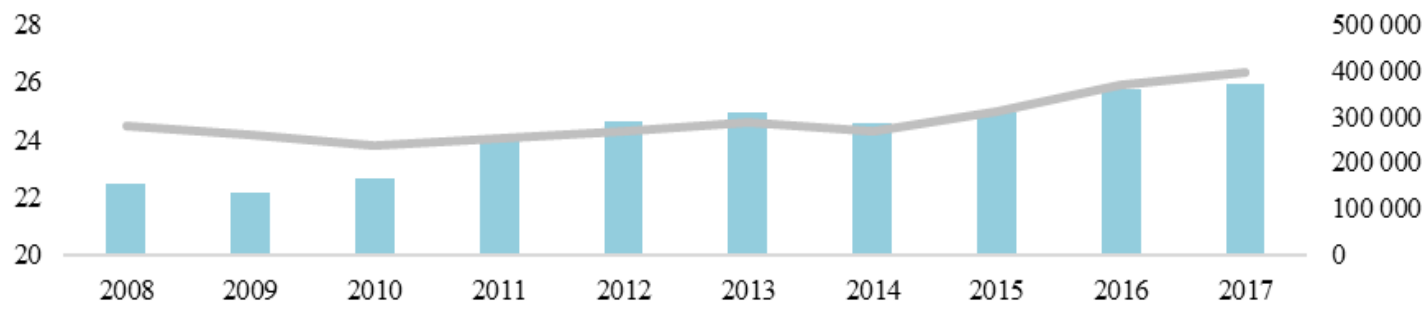

Average price of accommodation (in $€$ ) $\quad$ Revenue of accomodation (in thous. $€$ )

Source: Our own processing

Based on the analysis of the profit potential in tourism, we found that the development of the average price followed the development of the number of visitors. In the period under review, the average price for accommodation was increasing steadily, except in the years 
2009 and 2014. The highest price for accommodation in Slovakia was quantified in 2017, when visitors paid approximately $€ 26$ per night. On the other hand, the cheapest accommodation was offered in 2009 , when the price of accommodation was approximately $€$ 22. On average for the years $2008-2017$, the average price in Slovakia was $€ 24$.20. Changes in price development as well as the overall economic situation in the country largely determined the development of generated revenues in tourism. Looking at the chart, we may see that over the period analysed, total sales (approximately $€ 115,243,749$ ) increased, with the lowest sales having been achieved in the year 2010. During the years 2008-2014, sales did not exceed $€ 300$ million, while after 2015, their value increased significantly year on year and in 2017 it reached $€ 400$ million. On average for the years 2008 - 2017, sales of accommodation facilities were at the level of $€ 293,521,157$.

\subsection{Determining and drawing the impact of tourism on unemployment}

The following section shows the appropriateness of using of the instruments of analysis. The following Table 2 shows the basic outputs of descriptive statistics of the variables in question.

Table 2

Descriptive statistics on tourism indicators

\begin{tabular}{|c|c|c|c|c|c|c|c|c|}
\hline \multicolumn{2}{|c|}{ Descriptive Statistics } & DV & $\mathbf{A}$ & B & $\mathbf{C}$ & D & $\mathbf{E}$ & $\mathbf{F}$ \\
\hline \multicolumn{2}{|l|}{$\overline{~ M e a n ~}$} & 11.06 & 425.21 & $2.40 \times 10^{4}$ & $5.09 \times 10^{5}$ & $1.48 \times 10^{6}$ & 24.20 & $3.67 \times 10^{7}$ \\
\hline \multicolumn{2}{|l|}{ Median } & 10.80 & 317.00 & $2.19 \times 10^{4}$ & $3.66 \times 10^{5}$ & $1.34 \times 10^{6}$ & 23.74 & $2.86 \times 10^{7}$ \\
\hline \multicolumn{2}{|c|}{ Std. Deviation } & 5.11 & 226.52 & $8.39 \times 10^{3}$ & $2.98 \times 10^{5}$ & $7.11 \times 10^{5}$ & 5.02 & $2.16 \times 10^{7}$ \\
\hline \multicolumn{2}{|c|}{ Skewness } & 0.22 & 1.09 & $5.61 \times 10^{-1}$ & $1.12 \times 10^{0}$ & $5.20 \times 10^{-1}$ & 1.22 & $1.19 \times 10^{0}$ \\
\hline \multicolumn{2}{|l|}{ Kurtosis } & -1.00 & -0.03 & $-8.76 \times 10^{-1}$ & $6.12 \times 10^{-1}$ & $-8.73 \times 10^{-1}$ & 1.57 & $1.03 \times 10^{0}$ \\
\hline \multicolumn{2}{|l|}{ Minimum } & 2.27 & 195.00 & $1.33 \times 10^{4}$ & $2.18 \times 10^{5}$ & $5.38 \times 10^{5}$ & 16.72 & $1.37 \times 10^{7}$ \\
\hline \multicolumn{2}{|l|}{ Maximum } & 20.81 & 988.00 & $4.21 \times 10^{4}$ & $1.45 \times 10^{6}$ & $3.10 \times 10^{6}$ & 40.44 & $1.08 \times 10^{8}$ \\
\hline \multirow{2}{*}{ Percentiles } & 25 & 6.76 & 262.75 & $1.60 \times 10^{4}$ & $2.67 \times 10^{5}$ & $9.38 \times 10^{5}$ & 21.05 & $2.08 \times 10^{7}$ \\
\hline & 75 & 14.80 & 550.75 & $3.05 \times 10^{4}$ & $7.36 \times 10^{5}$ & $2.11 \times 10^{6}$ & 25.46 & $5.03 \times 10^{7}$ \\
\hline
\end{tabular}

Notes:

The dependent variable (DV) : Unemployment rate (\%).

The independent variables (IV) included the following selected indicators: A: Number of accommodation facilities; B: Number of beds; C: Number of visitors in accommodation facilities; D: Number of visitor's overnight stays; E: Average price of accommodation (in $€$ ); F: Revenue of ccommodation (in $\epsilon$ ).

Source: Our own processing in the R software

Table 2 describes the outcomes of basic descriptive statistics. Characteristics of the central tendencies (mean, median) shows information about center value, and if we are comparing those value, we take information about outliers in variables. Variability determines Standard Deviation (Std. Deviation) like universal characteristic of variability, with have ability to express exact deviations from the mean. Skewness a Kurtosis like indicators of position, determined to deviations from the normal distribution, which can be very freely described at interval from -1 to 1 . Minimal and maximal values delimit data distribution and together with 25 . and 75 . Percentiles (1. and 3. quartile) complete the vision about variables.

As can be predicted, the goal will be met based on the regression analysis outputs. The Figure 3 shows primarily the relationship of independent variables. The linkage analysis was one of the conditions through which regulatory regression was selected. 


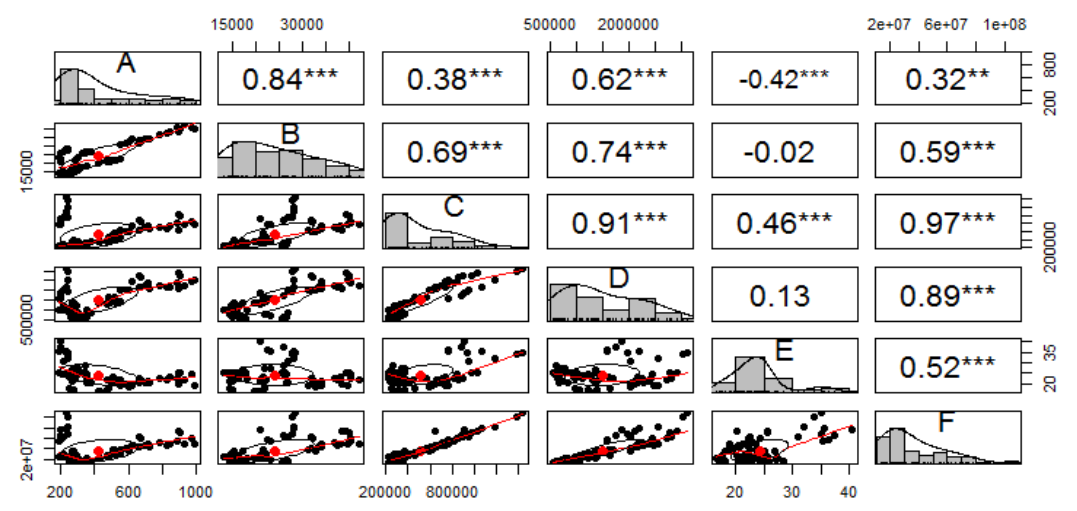

Notes:

A: Number of accommodation facilities, B: Number of beds, C: Number of visitors in accommodation facilities, D: Number of visitor's overnight stays, E: Average price of accommodation (in $€$ ), F: Revenue of accommodation (in $€$ ).

Source: Our own processing in the R software

As may be inferred, there exists a high degree of correlation among several independent variables, so the multicolinearity condition that is important in the BLUE model is unlikely to be met by the Gauss-Markov theorem. This assumption is also complemented by the VIF (Variance Inflation Factors), where the lowest value for the variable "Average cost of accommodation facilities in $€$ " is approximately 6.31 and the highest value for the variable "Number of visitors in accommodation facilities" is 35.11. When testing constant variation of the residuals (homoscedasticity), the value of Breusch-Pagan p is 0.0021 , so it is impossible to say that the second condition of the theorem (homoscedasticity) is met. For these reasons, we will proceed to a regression analysis based on cross validation through the classical OLS model as well as control-based models, namely Ridge, Lasso, Elastic Net and also Linear Model. Sum standard error of the given models is shown by the functions (1) - (4) in methodological part.

Output work in the context of the main goal of the paper was divided into three logical parts. The first part was devoted to estimation of parameters of individual models, in the second part we chose the most suitable model, which was subsequently verified on the outputs of the TRAIN and TEST set predictions. In the final part, the model outputs were determined.

\section{Ridge model}

As it is possible to assess from the SSE (sum square error) equations (1), (2) and (3) an important role in regulation is played by the parameter $\lambda$ and for elastic net regression (3) also the parameter $\alpha$. The next figures show the levels of these values. 
Figure 4

Visualization $\lambda$ RIDGE regression

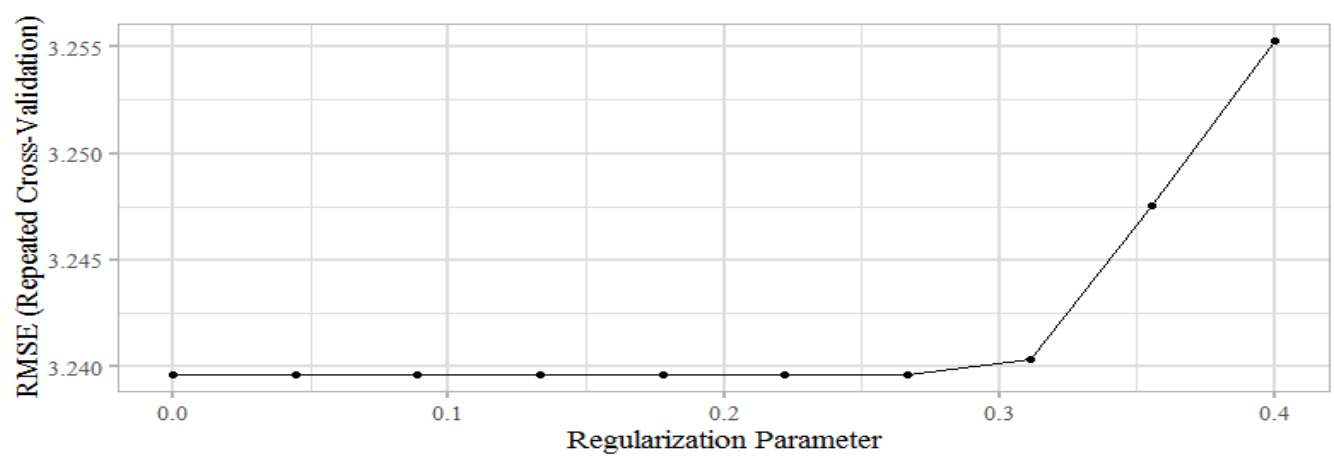

Source: Our own processing in the R software

For ridge regression (1), the control parameter $\lambda$ was defined at 0.267 . This parameter was calculated based on decadic cross validation at ten repetitions.

\section{Lasso model}

Figure 5

Visualization $\lambda$ LASSO regression

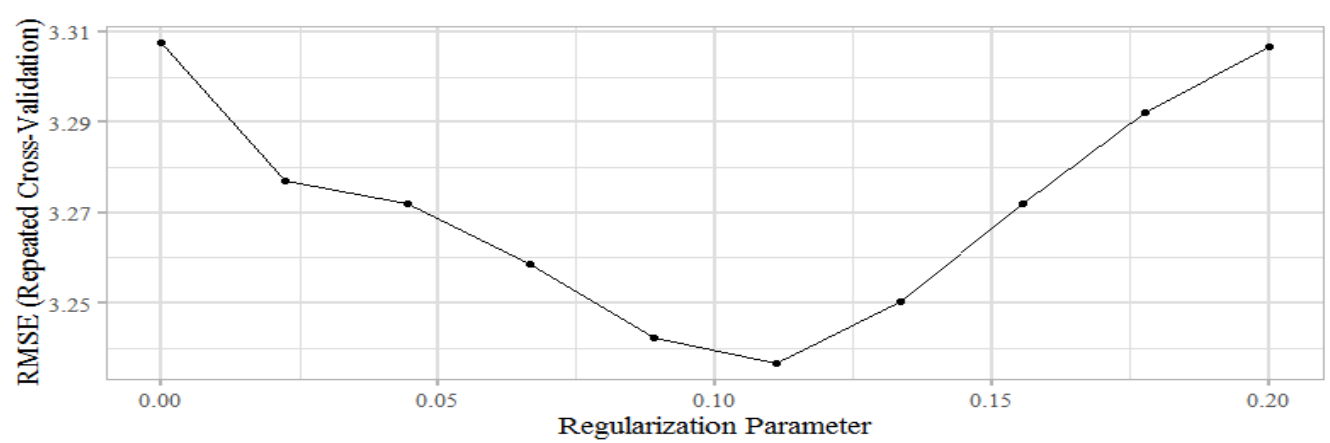

Source: Our own processing in the R software

For lasso regression (2), the $\lambda$ regulatory parameter was defined at 0.111 . This parameter was calculated based on decadic cross validation at ten repetitions.

\section{Elasic net model}

Figure 6

Visualization $\lambda$ and $\alpha$ ELASTIC NET regression

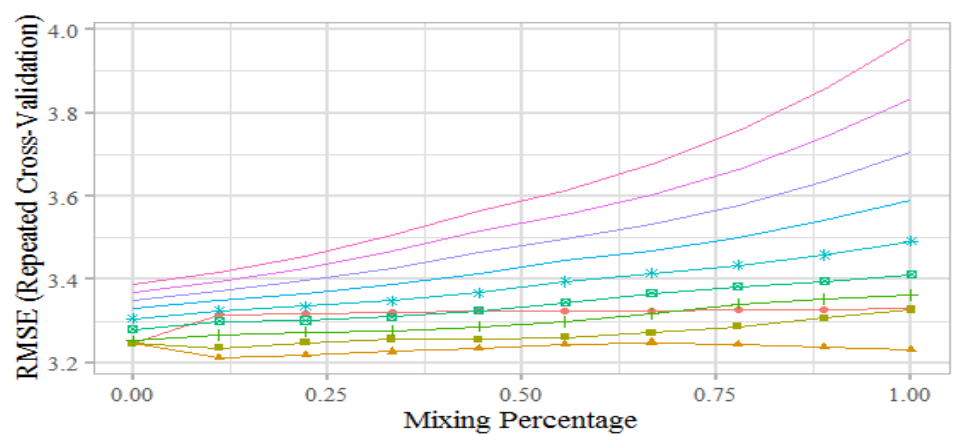

Regularization Parameter

$\rightarrow 0.0001$

$+0.1112$

$-0.2223$

$+0.3334$

ॠ 0.4445

* 0.5556

0.6667

- 0.7778

- 0.8889

Mixing Percentage

Source: Our own processing in the R software 
For elastic net regression (3), the regulatory parameter $\lambda$ was defined at 0.111 and the $\alpha$ parameter at the level 1 . These parameters were calculated based on decadic cross validation at ten replicates.

The Table 3 shows root mean square error (RMSE) and R2 determined on the basis of decimal cross validation at five repetitions. Highlighted values represent the best ranking in the given characteristic.

Table 3

Models Validity - RMSE a $\mathbf{R}^{2}$

\begin{tabular}{|c|c|c|c|c|c|c|c|}
\hline & & & & & & & \\
\hline & & Min. & Q1 & Median & Mean & Q3 & Max. \\
\hline \multirow{4}{*}{ RMSE } & Linear model & 1.657 & 2.924 & 3.459 & 3.490 & 4.026 & 5.254 \\
\hline & Ridge model & 1.433 & 2.983 & 3.450 & 3.501 & 4.119 & 5.348 \\
\hline & Lasso model & 1.610 & 2.918 & 3.458 & 3.481 & 3.990 & 5.289 \\
\hline & Elastic net model & 1.492 & 2.916 & 3.426 & 3.464 & 4.024 & 5.306 \\
\hline \multirow{4}{*}{$\mathbf{R}^{2}$} & Linear model & 0.130 & 0.425 & 0.644 & 0.578 & 0.757 & 0.935 \\
\hline & Ridge model & 0.134 & 0.441 & 0.648 & 0.586 & 0.757 & 0.930 \\
\hline & Lasso model & 0.130 & 0.429 & 0.626 & 0.581 & 0.756 & 0.936 \\
\hline & Elastic net model & 0.133 & 0.430 & 0.656 & 0.589 & 0.756 & 0.935 \\
\hline
\end{tabular}

Source: Our own processing in the R software

In terms of multiple parameters, the Elastic net model appears to be the most appropriate model. This judgment is confirmed by the previous Table 3 in which the most appropriate model values are highlighted.

Table 4

Comparison Train a Test model

\begin{tabular}{ccccc} 
& Linear model & Ridge model & Lasso model & Elastic_net model \\
\cline { 2 - 5 } TRAIN & 2.947487 & 3.056788 & 3.063072 & 3.063084 \\
TEST & 4.332940 & 4.418161 & 4.585254 & 4.585214 \\
Dif & 1.385453 & 1.361373 & 1.522182 & 1.522130 \\
\hline \hline
\end{tabular}

Source: Our own processing in the R software

According to the outputs of the comparison of TRAIN and TEST predictions, it is possible to assume that the best model is Rigde regression and the second best is the linear model. The outputs were therefore taken into account for all 4 models in the next part of the paper.

The previous chart of importance shows that the highest importance in the issue of unemployment is embodied in the factor E (Average price of accommodation) and then in factor A (Number of accommodation facilities). From this it can be concluded that in the area of tourism, the two factors are the most significant determinants of the development of unemployment in Slovakia. 


\section{Importance of impact}
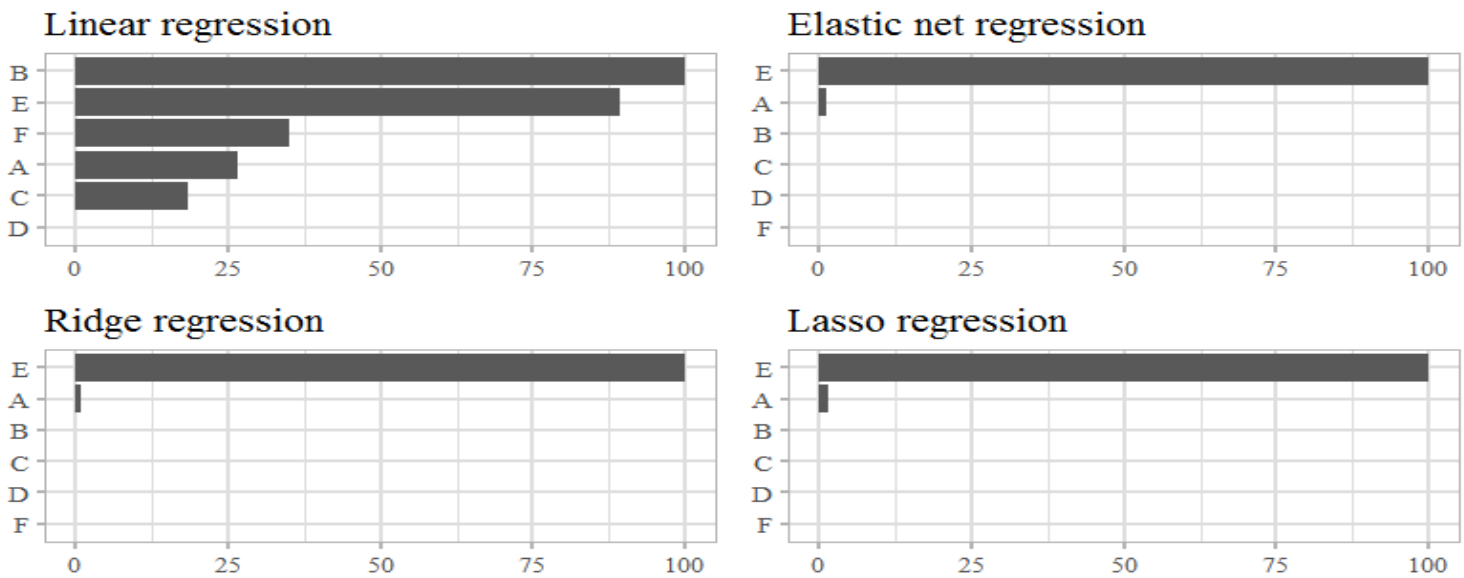

Key:

A: Number of accommodation facilities, B: Number of beds, C: Number of visitors in accommodation facilities, D: Number of visitor's nights, E: Average price of accommodation (in $€$ ), F: Revenue of accommodation (in $€$ ).

Source: Our own processing in the R software

For the exact definition of the impact, we applied a simple regression analysis (Figure 8). Unemployment (in \%) entered the analysis as a dependent variable, and the average price for accommodation (in $€$ ), the variable of the highest importance in the previous analysis in models (1), (2) and (3), entered as an independent variable. In the first step, the normality of the residues was analyzed, where the p output of the Shapiro-Wilk test takes the value of 0.736. Thus, we consider the condition of normality fulfilled. According to Gauss and Mark theorem in BLUE estimation, the conditions of heteroscedasticity and collinearity must be met, since in our case it is a simple OLS model, only heteroscedasticity is significant. Breusch-Pagan test takes $\mathrm{p}$ value of 0.009352 , so there is a significant heretoscedasticity in the models. Its solution was done using Covariance Matrix Estimation HC3, where Long, Laurie (1998) recommend this estimator for samples of up to 250 observations.

Table 5

Output of OLS model

Intercept

Average price accommodation

\begin{tabular}{cccc}
\hline Estimate $(\boldsymbol{\beta})$ & Std. Error & $\mathbf{t}$ value & $\operatorname{Pr}(>|\mathbf{t}|)$ \\
\hline \hline 25.164575 & 2.069927 & 12.1572 & $2.2 \mathrm{e}-16$ \\
-0.582585 & 0.074704 & -7.7985 & $2.309 \mathrm{e}-11$ \\
\hline
\end{tabular}

Source: Our own processing in the R software

The residual standard error was of the value of 4.216, and at 78 degrees of freedom, the determination coefficient was 0.3187 . The value of $p$ is less than 0.01 for both the independent variable and the constant, i.e. it is a statistically significant model. The coefficient took a negative value, i.e. the unemployment rate decreases with the rising average price for accommodation. 


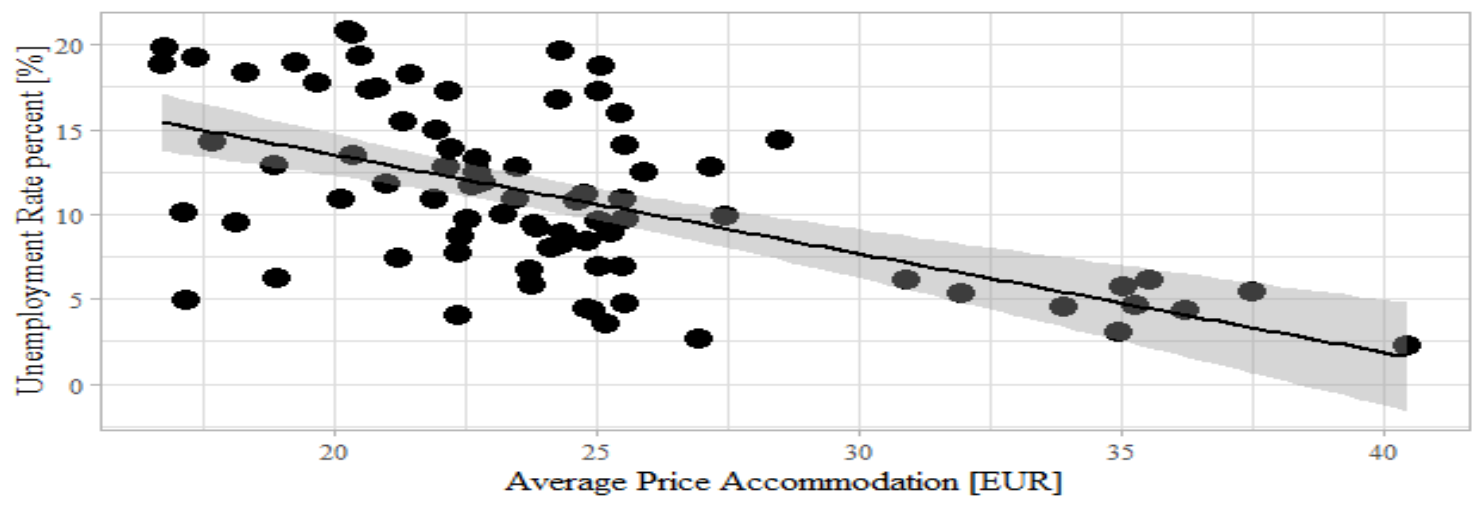

Source: Our own processing in the R software

\section{Discussion}

In this section, we focused on comparing above-mentioned results of presented paper to other scientific papers. Similar findings in this research area were confirmed by Umamaheswari, Amuthadevi, Ganesan (2018). Authors presented that, tourism revenues are the significant wellspring of pays, so revenues in tourism contribute to increase of employment ratio. Another view on relationship between tourism and unemployment was provided by Kakoudakis, McCabe, Story (2017). Findings revealed that tourism has potential to descrease the unemployment, as positive effects are identified by authors with regard to behaviours towards alternative paths to employment, such as part time jobs or volunteering. As stated by Supriyadi, Kausar (2017), the tourism sector has an important role in economy for the income resources and to create a job. Using the econometric model, authors confirmed the impact of tourism (represented by number of inbound-tourists) to unemployment and poverty in Indonesia. In presented research context, Schubert (2013) investigated the effects of an increase tourism on unemployment in a small open economy. The author developed a short-run, two-sector model with separated non-Walrasian labour markets, characterized by search of the Pissarides type. The created model supported the popular view that increase of tourism can reduce unemployment. According to Belas, Belas, Cepel, Rozsa (2019), countries' political environments shape the behavior of entrepreneurs significantly. As stated by Mura, Kljucnikov (2018), it requires more support, cooperation and better administrative and legislative background, which have been highlighted by experts and entrepreneurs.

However, Yabuuchi (2015), who argues that promoting tourism increases the risk of unemployment as opposed to agricultural production, takes the opposite view. Reducing agricultural production leads to higher unemployment, as not all of the unemployed persons will find work in the manufacturing sector. Thus, in the author's opinion, promoting tourism increases unemployment because of the unexpected effect of resource allocation. Furthermore, research dealing with the opposite influence of variables was presented by Alegre, Pou \& Sard (2019). Since the unemployment rate is strongly correlated with the economic cycle, the hypothesis that was discussed concerns whether residents' decision to participate in tourism is affected by the level of unemployment. The results that were obtained for a set of EU countries show that the unemployment level has a positive effect on the probability of not going on holidays.

Despite the different approaches of the authors in the perception of the relationship between tourism and unemployment, based on our knowledge and paper results, we agree with the views of many authors (see Literature review) who have confirmed the relationship 
between unemployment and tourism revenue. In our opinion, the authors are not concerned with the analysis of average price of accommodation in relation to unemployment rate, especially not in conditions of Slovakia. However, many studies are devoted to the analysis of tourism revenues which are generated mainly by price. The employment in tourism industry is also measured in detail by the UNWTO (2014). The objective is to improve the reliability and comparability of the data on employment in tourism, as well as to setting up and testing statistical indicators for measuring progress.

\section{Conclusion}

Tourism sector is a rapidly growing phenomenon and tourism activities, taken as a whole, contributes to sustainable economic development. This upward trend looks likely to continue into the future, because economic, political and environmental conditions have changed, and people were spending their leisure differently than in the past. Moreover, tourism leads to many social and economic changes, because it comprehensively interferes with all the components of its macro-environment.

The main objective of the paper was to deduce the impacts of the selected indicators of capacity and performance of tourism on the socio-economic development of the Slovak economy in the context of the registered unemployment rate. The research was carried out for the years 2008 - 2017 at the NUTS 3 level. For the correct determination of the issue was to evaluate the development of the selected indicators affecting the trend of tourism development (number of accommodation facilities; number of beds; number of visitors in accommodation facilities; number of visitor's overnight stays; the average price of accommodation and revenue of accommodation) in Slovakia during the period under review.

Based on the analysis of capacity and profit potential, we reached the following conclusions. The results in the first part of the analysis focused on the assessment of tourism development assumptions represented by the capacity potential have shown that the decrease in the number of accommodation facilities, which was accompanied by a decrease in the number of beds, did not correspond to the increase in the number of visitors and the number of overnight stays. This fact points to the effective use of the existing accommodation capacities. The profitable potential of tourism in the period of $2008-2017$ was influenced in Slovakia by the rising prices for accommodation, which also stimulated the growth of revenues from accommodation, which in 2017 hit the level of $€ 400$ million. Findings confirm the growing trend of tourism sector in Slovak economy. As stated by Umamaheswari, Amuthadevi, Ganesan (2018), tourism is one of the significant divisions that control the economy of a nation. So, we can assume that tourism outputs significantly contribute to the unemployment ratio among other things.

In accordance with the main goal of the paper, the work on the outputs was then divided into three logical parts. The first part was devoted to the estimation of individual model parameters (Linear model, Ridge model, Lasso model and Elastic net model). In the next section, the most suitable model was selected, which was subsequently verified on the outputs of the TRAIN and TEST set predictions. According to the values of RMSE and R2 (Table 3), the Elastic net model proved most suitable as its values mostly represented the best rating in a given characteristic. According to the outcomes of the comparison of the TRAIN and TEST predictions, it was possible to assume that the best model was the Rigde regression model and the second best was the linear model. Due to different results when selecting the appropriate model, the outputs were taken into account for all 4 models. In determining and drawing the impact of selected indicators of capacity and tourism performance on the rate of registered unemployment in the period of 2008 - 2017, the highest importance in the issue of 
unemployment was included in the indicator "average price of accommodation" (factor E) and the indicator "number of accommodation facilities" (Factor A). It can be concluded from the given results that in the area of tourism, the two factors are the most significant determinants of the development of unemployment in Slovakia. A simple regression analysis was then applied for exact impact definition. The value of $\mathrm{p}$ was less than 0.01 for both the independent variable and the constant, i.e. it is a statistically significant model. The coefficient took a negative value (-0.582585), from which we conclude that the rate of registered unemployment is falling with the rising average price for accommodation. It is evident that accommodation facilities, whose use by visitors creates the conditions for the use of other complementary services, increases the attractiveness of tourist sites and the level of expenditure incurred by tourist visitors. When the rising incomes of tourism businesses are consumed, they enter the economic cycle and turn into consumer goods and services, capital goods, or finance - which means they go through multiple stages with a multiplier effect. This effect, among other things, raises the increased demand for labour, both in the tourism sector and in related sectors, and ultimately pushes down the registered unemployment rate.

However, our findings are also subjected to some limitations. The data unavailability can be considered as one of the main research limitations, since it was not possible to apply another tourism indicators. In the view of economic disparities and various geography conditions for tourism development, it is difficult to state whether the paper results are valid for another countries. Furthermore, it is difficult to compare unemployment and tourism in the context of different political situation of countries. Despite of the fact that tourism sector belongs to the fastest growing sectors in Slovakia, as it was already making a significant contribution to building long-term competitiveness through its performance, it is difficult to estimate the contribution of toursim sector on macroeconomic effects based on research results (it requires a deeper analysis). Another limitation of results consists in application of our findings in practice. In Slovakia, policy institutions have not created a comprehensive tourism strategy in relation to issue of unemployment, so the research results may be perceived as relatively general from the point of view policymakers.

For future research, the analysis of tourism indicators dependencies is recommended. The attention should be paid to prediction of tourism development. Moreover, the analysis of tourism sector should be extended and to examine the impact of other macroeconomic indicators, namely Gross Domestic Product (GDP) or average wage in economy. In our opinion, it is also important to focus on a deeper analysis of regional tourism conditions, to identify regional problems, as well as, to examine the impact of policy interventions.

In the context of this conclusions, we can stated that increasing of average price in whatever sector has positive effect for prosperity of economy. So, recommendation for practice - if economic cycle operates well, all economic outputs should be transfored into economic growth and to create better conditions for people. Paper results can be usefull in private sector. Nowdays, a large number of businesses operate in tourism (directly or in related sectors). Despite of the fact that the issue of increasing the price is not desirable from the point of view all parties concerned, it is important to realise that the rising incomes of tourism businesses enter the economic cycle and turn into consumer goods and services, and this effect raises the increased demand for labour. The contribution of reasearch results is usefull also for policymakers. In keeping with reasearch results, the significantly relationships between tourism sector and unemployment ratio are undeniable, so policymakers should create suitable enterprise environment and conditions in tourism sector.

It might seem that the link between tourism and the unemployment rate is not so significant. However, research results show that average price of accommodation strongly determines the development of this sector. It is also importantg to note that there is an inversely proportional relationship between the variables examined. Although price increases 
in any sector are not desirable, it should become aware that higher prices and thus higher incomes of tourism businesses can contribute to the effective functioning of the economic cycle and then leads to increasing of employment. For practice, from the perspective of private sector, we recommend to pay more attention to analyse of price for goods or services provided. In public sector, policymakers should protect natural resources, monitor economic conditions and to support toursim sector by subsidies in order to develop tourism sector that leads to decrease of unemployment ratio.

\section{Acknowledgements}

This research paper has been elaborated within the framework of the APVV-17-0166 project, "Economic and Psychological Factors of Tourists' Expenditures: Microeconometric Modeling".

\section{References}

1. Alegre, J., Pou, L., \& Sard, M. (2019) High unemployment and tourism participation. $\begin{array}{llll}\text { Current Issues in } & \text { 1138-1149, }\end{array}$ https://doi.org/10.1080/13683500.2018.1464550.

2. Ali, A. (2018). Travel and tourism: Growth potentials and contribution to the GDP of Saudi Arabia. Business Perspectives: Problems and Perspectives in Management, 16(1), 417-427. http://dx.doi.org/10.21511/ppm.16(1).2018.39.

3. Badelescu, D., Badelescu, A., \& Bac, D. (2015). Tourism and poverty in developing countries: The case of India and Romania. Journal of tourism - Studies and research in tourism, 20(20), 27-33. Retrieved from https://www.researchgate.net/publication/288666771_TOURISM_AND_POVERTY_ IN_DEVELOPING_COUNTRIES_THE_CASE_OF_INDIA_AND_ROMANIA.

4. Bakri, N., M., Jaafar, M., \& Mohamed, D. (2014). Perceptions of Local Communities on the Economic Impacts of Tourism Development in Langkawi, Malaysia. $4^{\text {th }}$ international conference on tourism research, 12(2014), 1-9. https://doi.org/10.1051/shsconf/20141201100.

5. Banday, U., J., \& Ismail, S. (2017). Does tourism development lead positive or negative impact on economic growth and environment in BRICS countries? A panel data analysis. Economics Bulletin, 37(1), 553-567. Retrieved from https://ideas.repec.org/a/ebl/ecbull/eb-16-00574.html.

6. Belas, J., Belas, L., Cepel, M., \& Rozsa, Z. (2019). The impact of the public sector on the quality of the business environment in the SME segment. Administratie si Management Public, (32), 18-31. https://doi.org/10.24818/amp/2019.32-02.

7. Bunghez, C., L. (2016). The importance of tourism to a destination's economy. Journal of Eastern Europe Research in Business \& Economics, 2016(2016), 1-9. https://doi.org/10.5171/2016.143495.

8. Camilleri, M., A. (2018). The tourism industry: An overview. Travel Marketing, Tourism Economics and the Airline Product, 1, 3-27. https://doi.org/10.1007/978-3319-49849-2_1.

9. Cepel, M., Stasiukynas, A., Kotaskova, A., Dvorsky, J. (2018). Business Environment Quality Index in the SME Segment. Journal of Competitiveness, 10(1), 21-40. https://doi.org/10.7441/joc.2018.02.02 
10. Dobrovič, J., Urbanski, M., Gallo, P., Benkova, E. \& Čabinová, V. (2018). Balanced scorecard concept as a tool of strategic management and its usage in the construction industry. Polish Journal of Management Studies, 18(2), 59-72. https://doi.org/10.17512/pjms.2018.18.2.05.

11. Eusebio, C., Carneiro, M., J., Kastenholz, E., \& Alvelos, H. (2016). The impact of social tourism for seniors on the economic development of tourism destinations. European Journal of Tourism Research, 12, 5-24. Retrieved from http://ejtr.vumk.eu/index.php/volume12/281-

v12125theimpactofsocialtourismforseniorsontheeconomicdevelopmentoftourismdestin ations.

12. Fiala, R. (2017). Testing Convergence toward Gibrat's Law for Czech Manufacturing Firms. Journal of Economics, 65(8), 737-750. Retrieved from: https://www.sav.sk/journals/uploads/1027125208\%2017\%20Fiala\%20+\%20RS.pdf

13. Gallo, P., Mihalčová, B., Gallo, Jr., P., Čabinová, V., \& Tomčíková, L'. (2018). Application of the Balanced scorecard as a strategic management tool in practice: A case of Slovak tourism sector. GeoJournal of Tourism and Geosites, 24(1), 19-28. https://doi.org/10.30892/gtg.24102-339.

14. Ghosh, S. (2019). Uncetainty, economic growth its impact on tourism, some country experiences. Asia Pacific Journal of Tourism Research, 24(1), 83-107. https://doi.org/10.1080/10941665.2018.1542324.

15. Gregorová, B., Neradný, M., Klaučo, M., Masný M., \& Balková N. (2015). Tourism and regional development. Matej Bel University in Banská Bystrica.

16. Hamarneh, I., \& Királová, A. (2016). Food tourism in the Czech Regions - Trends and Opportunities. Geographical Information, 20(2), 96-110. https://doi.org/10.17846/GI.2016.20.2.96-110.

17. Hedija, V., Fiala, R., \& Kuncová, M. (2017). Is profitability a good proxy for efficiency? Evidence from the subsector of tour operators. Review of Economic Perspectives, 17(4), 425-440. https://doi.org/10.1515/revecp-2017-0022.

18. Holešinská, A. (2012). Destination management as a tool of regional tourism policy. Masaryk University, Brno, $154 \mathrm{p}$.

19. Kadriu, A. (2016). Tourism development and its impact on the overall economic and environmental development of the country. Journal of Environmental Protection and Ecology, 17(1), 268-275. Retrieved from https://www.cabdirect.org/cabdirect/abstract/20163177266.

20. Kajzar, P. (2018). A tourism trends and development of selected economic indicators in the Moravian - Silesian region between 2006 - 2016. Acta Oeconomica Universitatis Selye, 7 (1), 46-57. Retrieved from http://acta.ujs.sk/docs/acta\%207_1\%20print.pdf.

21. Kakoudakis, K, I., McCabe, S., \& Story, V. (2017). Social tourism and self-efficacy: Exploring links between tourism participation, job-seeking and unemployment. Annals of Tourism Research, 65(2017), 108-121. https://doi.org/10.1016/j.annals.2017.05.005

22. Karaoulanis, A. (2018). Tourism in developing countries. The path towards sustainable development and its interaction with the local communities, the environment and the human factor. Socio Economic Challenges, 2(4), 80-86. https://doi.org/10.21272/sec.4(2).80-86.2018

23. Kiseláková, D., Šofranková, B., Čabinová, V., \& Šoltesová, J. (2018). Analysis of enterprise performance and competitiveness to streamline managerial decisions. Polish Journal of Management Studies, 17(2), 101-111. https://doi.org/10.17512/pjms.2018.17.2.09. 
24. Kotíková, H. (2013). New trends in tourism supply. $1^{\text {st }}$ edition. Praha: Grada Publishing. 208 p.

25. Kot, S. (2018). Sustainable supply chain management in small and medium enterprises. Sustainability, 10(4), 1-19. https://doi.org/10.3390/su10041143.

26. Latifian, N., Madahi, S., M., \& Mabhout, M. (2018). Providing a model to analyze the impact of tourism development on sustainable economic growth: comparison of European developed and Asian developing countries. National academy of managerial staff of culture and arts herald, 2, 221-228.

27. Long S., L., \& Laurie H., E. (1998). Correcting for Heteroscedasticity with Heteroscedasticity Consistent Standard Errors in the Linear Regression Model: Small Sample Considerations. 1-33. Retrieved from http://www.indiana.edu/ jslsoc/files_research/testing_tests/hccm/98TAS. pdf.

28. Malec, L., \& Királ'ová, A. (2018). Evaluating competencies of graduates in tourism as a prerequisite for future employability. Prague Economic Papers, 2018(2), 196-214. https://doi.org/10.18267/j.pep.651.

29. Mertlova, L., \& Smith, V. (2014). The impact of the global economic crisis on the development of tourism in the Czech Republic. $9^{\text {th }}$ International Conference on Topical Issues of Tourism - Tourism and its Impacts on Society, 171-181.

30. Ministry of Transport and Construction of the Slovak Republic (MTCRD SR). (2018). Zákon č. 91/2010 Z. z. o podpore cestovného ruchu - účinnost' od 01.01.2014 (úplné znenie). Retrieved from https://www.zakonypreludi.sk/zz/2010-91.

31. Mishchuk, H., Samoliuk, N., Bilan, Y. (2019). Measuring social justice in the light of effectiveness of public distributive policy. Administratie si Management Public, (32), pp. 63-76, DOI: 10.24818/amp/2019.32-05.

32. Modica, P., Capocchi, A., Foroni, I., \& Zenga, M. (2018). An assessment of the implementation of the European tourism indicator system for sustainable destinations in Italy. Sustainability, 10(9), 1-21. https://doi.org/10.3390/su10093160.

33. Mura, L., Kljucnikov, A. (2018). Small Businesses in Rural Tourism and Agrotourism: Study from Slovakia. Economics \& Sociology, 11(3), 286-300. Retrieved from https://economics-sociology.eu/files/17_627_Mura_Kljucnikov.pdf

34. Ohanyan G., Androniceanu, A. (2017), Evaluation of IMF program effects on employment in the EU, Acta Oeconomica, 67(3), 311-332. https://doi.org/10.1556/032.2017.67.3.2.

35. Page, S. J. (2015). Tourism management. $5^{\text {th }}$ edition. Routledge, London, $465 \mathrm{p}$.

36. Petcu, M., A., \& Cismasu, I., D. (2019). Tourism: A contribution to the sustainable economic growth. Quality - Access to Success, 20(2), 460-466. Retrieved from https://www.srac.ro/calitatea/en/arhiva_supplements.html.

37. Plzakova, L., \& Studnicka, P. (2014). Decreasing of regional disparities in the field of unemployment due to tourism development on a local level. Hradec Králové Economic Days 2014: Economic development and management of the region, 432444.

38. Pratt, S. (2015). Potential Economic Contribution of Regional Tourism Development in China: A comparative analysis. International Journal of Tourism Research, 17(3), 303-312. https://doi.org/10.1002/jtr.1990.

39. Pulido-Fernandez, J. I., \& Pulido-Fernandez, M. D. (2018). Proposal for an indicators system of tourism governance at tourism destination level. Social Indicators Research, 137(2), 695-743. https://doi.org/10.1007/s11205-017-1627-z. 
40. Purwomarwanto, Y., L., \& Ramachandran, J. (2015). Performance of tourism sector with regard to the global crisis - a comparative study between Indonesia, Malaysia and Singapore. The Journal of Developing Areas, 49(4), 325-339. https://doi.org/10.1353/jda.2015.0149.

41. Roy, S. Ch., \& Roy, M. (2015). Tourism in Bangladesh: Present Status and Future Prospects. International Journal of Management Science and Business Administration, 1(8), 53-61. http://dx.doi.org/10.18775/ijmsba.1849-5664-5419.2014.18.1006.

42. Schmude, J., Zavareh, S., Schwaiger, K., M., \& Karl, M. (2018). Micro-level assessment of regional and local disaster impacts in tourist destinations. Tourism Geographies, 20(2), 290-308. https://doi.org/10.1080/14616688.2018.1438506

43. Schubert, S., F. (2013). Unemployment dynamics in a short-run two-sector model of a tourism exporting small open economy. Tourism Economics, 19(5), 1049-1076. https://doi.org/10.5367/te.2013.0334.

44. Semenenko, I., Halhash, R., \& Sieriebriak, K. (2019). Sustainable development of regions in Ukraine: before and after the beginning of the conflict. Equilibrium. Quarterly Journal of Economics and Economic Policy, 14(2), 317-339. https://doi.org/10.24136/eq.2019.015.

45. Simionescu, M. (2016). Competitiveness and Economic Growth in Romanian Regions. Journal of Competitiveness, 8(4),46 - 60. https://doi.org/10.7441/joc.2016.04.03.

46. Statistical Office of the Slovak Republic (SOSR). (2019). Registered unemployment in Slovakia. [online]. Retrieved from http://statdat.statistics.sk/cognosext/cgibin/cognos.cgi?b_action=cognosViewer\&ui.action=run\&ui.object $=$ storeID $(\% 22 \mathrm{i} 3623$ 4AC7F97A407FA10FB0E47B7C0EEB\%22)\&ui.name=Miera\%20evidovanej\%20nez amestnanosti $\% 20 \% 5 \mathrm{bpr} 3108 \mathrm{rr} \% 5 \mathrm{~d} \&$ run.outputFormat=\&run.prompt=true\&cv.header $=$ false \&ui.backURL=\%2fcognosext $\% 2 \mathrm{fcps} 4 \% 2 \mathrm{fportlets} \% 2 \mathrm{fcommon} \% 2 \mathrm{fclose} . \mathrm{html} \& \mathrm{r}$ un.outputLocale $=$ sk\#

47. Statistical Office of the Slovak Republic (SOSR). (2019). Tourism Satellite Account. [online]. http://datacube.statistics.sk/\#!/view/sk/VBD_SK_WIN/cr3001rr/Kapacity\%20a\%C2\% A0v\%C3\%BDkony\%20ubytovac\%C3\%ADch\%20zariaden\%C3\%AD\%20pod\%C4\% BEa\%20krajov\%20\%20ro\%C4\%8Dn\%C3\%A9\%20\%C3\%BAdaje\%20\%5Bcr3001rr\%5D

48. Strielkowski, W. (2018). Heritage, screen and literary tourism. Tourism Management, 69, 537-537. https://doi.org/10.1016/j.tourman.2018.07.004.

49. Schubert, S. F. (2013). Unemployment dynamics in a short-run two-sector model of a tourism exporting small open economy. Tourism Economics, 19(5), 1049-1076. https://doi.org/10.5367/te.2013.0334

50. Sultana, S. (2016). Economic Contribution of Tourism Industry in Bangladesh. Journal of Tourism, Hospitability and Sports, 22(2016). Retrieved from https://www.researchgate.net/publication/318502913_Economic_Contribution_of_To urism_Industry_in_Bangladesh.

51. Supriyadi, E., \& Kausar, D. R. K. (2017). The economic impact of international tourism to overcome the unemployment and the poverty in Indonesia. Journal of Environmental Management and Tourism, 8(2), 451-459. https://doi.org/10.14505/jemt.v8.2(18).18.

52. Šofranková, B., Kisel'áková, D., \& Horváthová, J. (2017). Actual question of risk management in models affecting enterprise performance. Journal of Economics, 65(7), 644-667. Retrieved from https://www.sav.sk/index.php?lang=sk\&doc=journal$\underline{\text { list\&part=list_articles\&journal_issue no }=11114187}$. 
53. Štefko, R., Fedorko, I., Bačík, R., \& Fedorko, R. (2015). An analysis of perceived topicality of website content influence in terms of reputation management. Polish Journal of Management Studies, 12(1), 177-185. Retrieved from https://pjms.zim.pcz.pl/resources/html/article/details?id=167289

54. Stefko, R., Bacik, R., \& Fedorko, R. (2017). City marketing and its impact on income sources of the local government. Polish Journal of Management Studies, 15(1), 244254. DOI: $10.17512 /$ pjms.2017.15.1.23

55. Štefko, R., Gavurová, B., \& Korony, S. (2016). Efficiency measurement in healthcare work management using malmquist indices. Polish Journal of Management Studies, 13(1), 168-180. https://doi.org/10.17512/pjms.2016.13.1.16.

56. Štefko, R., Kiral'ova, A., \& Mudrik, M. (2015). Strategic Marketing Communication in Pilgrimage Tourism. Procedia Social and Behavioral Sciences, 175, 423-430. https://doi.org/10.1016/j.sbspro.2015.01.1219.

57. Štefko, R., Vašaničová, P., Litavcová, E., \& Jenčová, S. (2018). Tourism Intensity in the NUTS III Regions of Slovakia. Jorunal of Tourism and Services, 9(16), 52-65. https://doi.org/10.29036/jots.v9i16.43.

58. Tüzemen, D. (2017). A New Estimate of the Natural Rate of Unemployment. Macro Bulletin, Federal Reserve Bank of Kansas City, 1-6. Retrieved from https://www.kansascityfed.org/ /media/files/publicat/research/macrobulletins/mb17tu zemen1129.pdf.

59. United Nations World Tourism Organization (UNWTO). (2018). UNWTO Tourism Highlights. [online]. Retrieved from https://www.eunwto.org/doi/pdf/10.18111/9789284419876.

60. United Nations World Tourism Organization (UNWTO). (2015). World conference on tourism and culture: Building and new partnership. Retrieved from http://www.eunwto.org/doi/book/10.18111/9789284417360.

61. United Nations World Tourism Organization (UNWTO). (2014). Measuring Employment in the Tourism Industries. Retrieved from https://www.eunwto.org/doi/pdf/10.18111/9789284416158.

62. Umamaheswari, R., Amuthadevi, C., \& Ganesan, R. (2018). Diminution of unemployment through Tourism industry using data mining. Journal of Computational and Theoretical Nanoscience, 15(6-7), 2395-2399. https://doi.org/10.1166/jctn.2018.7476

63. Vengesayi, S., Mavondo, F., T., \& Reisinger, Y. (2016). Tourism destination attractiveness: Attractions, facilities, and people as predictors. Tourism Analysis, 14(2016), 621-636. https://doi.org/10.3727/108354209X12597959359211.

64. Wanke, P., Figueiredo, O., H., D., \& Antunes, J., J., M. (2019). Unveiling endogeneity and temporal dependence between tourism revenues/expenditures and macroeconomic variables in Brazil: A stochastic hidden Markov model approach. Tourism Economics, 25(1), 3-21. https://doi.org/10.1177/1354816618787578.

65. World Economic Forum (WEF). (2017). Paving the way for a more sustainable and inclusive future. The Travel \& Tourism Competitiveness Report 2017. Retrieved from https://www.weforum.org/reports/the-travel-tourism-competitiveness-report-2017.

66. Yabuuchi, S. (2015). Environmental protection and tourism promotion with urban unemployment. The International Economy, 18, 31-41. Retrieved from https://www.pulib.sk:2350/10.1007/978-981-10-8615-1_8.

67. Yabuuchi, S. (2018). The effects of tourism promotion on unemployment and welfare in the presence of environmental protection and an agricultural subsidy. Recent developments in normative trade theory and welfare economics, 26(2018), 127-139. https://doi.org/10.1007/978-981-10-8615-1_8. 
68. Yrigoy, I. (2014). Population characteristics and the impact of tourism on economic development. Tourism Geographies, 16(4), 636-652. https://doi.org/10.1080/14616688.2014.889207.

\section{Brief description of Authors:}

\section{Ing. Mária Matijová}

Faculty of Management, University of Prešov in Prešov. Konštantínova 16, 08001 Prešov, Slovakia, http://www.unipo.sk/fm, email: matijovam.kf@gmail.com. Mária Matijová is a postgraduate student of the University of Prešov in Prešov. In her dissertation she is focusing on researching determinants of development and potential of the tourism industry in the Prešov region with regard to its competitiveness and sustainable development. Currently, she is a member of the project Vega research team (VEGA: 1/0470/18 Economic Activity of Tourism in the European Area).

\section{Mgr. Erika Onuferová}

Department of Finance, Faculty of Management, University of Prešov in Prešov, Konštantínova 16, $080 \quad 01$ Prešov, Slovakia, http://www.unipo.sk/fm, Email: erika.onuferova@smail.unipo.sk. Erika Onuferová is a PhD. student at the Department of Finance, Faculty of Management, University of Prešov in Prešov. Her dissertation thesis is focused on managerial approaches to improving enterprise performance and competitiveness using to streamline strategic management decision-making processes. She is currently the member of scientific projects APVV-15-0322 in cooperation with the University of Economics in Bratislava.

\section{Mgr. Martin Rigelský}

Department of Marketing and International Trade, Faculty of Management, University of Prešov in Prešov, Konštantínova 16, 08001 Prešov, Slovakia, http://www.unipo.sk/fm, Email: martin.rigelsky@smail.unipo.sk. Martin Rigelský is a PhD. student at the Department of Department of Marketing and International Trade, Faculty of Management, University of Prešov in Prešov. His Dissertation thesis and research activities are focused on services sector with a primary focused on the client behavior. Research activities have been centralized to health, tourism and service marketing in general. He is a member of research teams of several grant projects, where the most important is APVV-17-0166 "Economic and Psychological Factors of Tourists' Expenditures: Microeconometric Modeling".

\section{Ing. Vladislav Stanko, MBA}

Department of Marketing and International Trade, Faculty of Management, University of Prešov in Prešov, Konštantínova 16, 08001 Prešov, Slovakia, http://www.unipo.sk/fm, Email: stanko.vuc2017@,gmail.com. Vladislav Stanko is a postgraduate student of the University of Prešov in Prešov at the Department of Department of Marketing and International Trade, Faculty of Management. Research activities have been centralized to tourism and service, marketing and marketing services in general. 